\title{
Oxygen Toxicity in Neonatal Rats: The Effect of Endotoxin Treatment on Survival during and post- $\mathrm{O}_{2}$ Exposure
}

\author{
LEE FRANK \\ Department of Medicine, Pulmonary Research Laboratory, University of Miami School of Medicine, \\ Miami, Florida 33136
}

\begin{abstract}
Neonatal rats were treated with low doses of bacterial lipopolysaccharide (endotoxin) to test for a protective effect of endotoxin against $\mathrm{O}_{2}$ toxicity and the severe inhibition of normal lung development which occurs during prolonged exposure to hyperoxia. The rationale for the prophylactic use of endotoxin included its marked protective effect against pulmonary $\mathrm{O}_{2}$ toxicity in adult rats and its lung growth-promoting effect in experimental pulmonary stress models. Neonatal rats (4-5 days old) survived a 14-day exposure to $>95 \% \quad \mathrm{O}_{2}$ equally well whether treated with saline $(39 / 51=76 \%)$ or with endotoxin $(41 / 51=80 \%)$. However, during the following $24 \mathrm{~h}$ of gradual weaning to room air breathing, there was a marked difference in survival between the endotoxin group $(32 / 41=78 \%)$ and the saline pups $(14 / 39=36 \%)(p<$ $0.001)$. Both groups showed inhibition of lung development (alveolarization) during $\mathrm{O}_{2}$ exposure, but endotoxin treatment compared to saline was associated with increased specific lung volume (5.33 versus $4.50 \mathrm{ml} / 100 \mathrm{~g}$ ) (air control $=4.08$ ), smaller mean airspace diameter (mean linear intercept $=49.0$ versus $55.8 \mu \mathrm{m}$ ) (air control $=43.3$ ), increased specific internal surface area (4393 versus 3232 $\mathrm{cm}^{2} / 100 \mathrm{~g}$ ) (air control = 3753), and greater preservation of alveolar wall capillary patency $(24.83$ versus $18.52 \%$ "capillary density") (air control $=27.70 \%$ ). We conclude that endotoxin treatment resulted in significant protection against $\mathrm{O}_{2}$ toxicity in neonatal rats which was manifested during readaptation to room air breathing. The protective effect was likely due to a combination of reduced inhibition of lung growth and development and reduced hyperoxic damage to the respiratory membrane of the lung. (Pediatr Res 21: 109-115, 1987)
\end{abstract}

$\quad$ Abbreviations
SOD, superoxide dismutase
CAT, catalase
GP, glutathione peroxidase
G-6-PD, glucose-6-phosphate dehydrogenase
L $_{m}$, mean linear intercept
ISA, internal surface area
BPD, bronchopulmonary dysplasia

Newborn animals are known to be much more resistant than adult animals to the characteristic pathological changes of pul-

Received June 18, 1986; accepted September 11, 1986.

Correspondence and reprint requests to Lee Frank, M.D., Ph.D., Pulmonary Research R120, University of Miami School of Medicine, P. O. Box 016960. Miami. FL 33101.

Supported by NIH Grant HL26029 and NHLBI Research Career Development Award HLO1230. monary $\mathrm{O}_{2}$ toxicity $(1,2)$. However, there are unique pulmonary complications associated with prolonged hyperoxic exposure in the neonatal animal which could importantly influence both short and long-term survival post- $\mathrm{O}_{2}$ exposure. These complications relate to the known inhibitory action of hyperoxia on lung biosynthetic processes $(1,3,4)$, and the morphological consequences this inhibitory action has on the rapidly growing and differentiating newborn (animal) lung. Several studies have now demonstrated that early postnatal exposure to hyperoxia is associated with marked inhibition of the normal septation process by which the large saccular airspaces characteristic of the newborn lung are converted to mature smaller diameter alveoli (57). Interference with alveolarization in the neonatal lung may have permanent effects on lung morphology and function in laboratory animals and in humans (see "Discussion") $(6,8,9)$.

Bacterial endotoxin, used in small doses, has been shown consistently to reduce the manifestations of $\mathrm{O}_{2}$ toxicity and to markedly improve the survival of adult rats challenged with high $\mathrm{O}_{2}$ exposure (survival rate increased from $\sim 25 \%$ to $>95 \%$ ) (1013). Although the exact mechanism(s) of endotoxin's protective effect against $\mathrm{O}_{2}$ toxicity is not yet known, several important phenomena associated with endotoxin treatment have been elucidated. These include significant elevations of antioxidant enzyme activities in the lungs of $\mathrm{O}_{2}$-exposed endotoxin-treated adult rats (not found in untreated adult rats in high $\mathrm{O}_{2}$ ), and the apparent ability of endotoxin treatment to reverse the inhibitory action of hyperoxia on lung (protein and nucleotide) biosynthesis $(10,11,14,15)$. This latter effect associated with endotoxin treatment, plus the recent demonstration that endotoxin treatment accelerates compensatory lung growth in adult rats subjected to pneumonectomy (16), provided the rationale for these present studies. We reasoned that if endotoxin treatment were to have these same (growth-promoting) effects in neonatal rats exposed to prolonged high $\mathrm{O}_{2}$, then we might expect to find: 1) improved survival of the neonatal animals during and/or post$\mathrm{O}_{2}$ exposure and 2) evidence for less marked $\mathrm{O}_{2}$-induced inhibition of lung growth and alveolarization in the endotoxin-treated pups. The results described herein do indicate a definite protective effect of endotoxin treatment on survival post- $\mathrm{O}_{2}$ exposure, but do not allow for definitive conclusions about the mechanism for the substantial protective effect that was realized with endotoxin treatment.

\section{METHODS}

Animals/treatments. Sprague-Dawley albino neonatal rats from our own breeding colonies were used. The adult female rats were originally obtained from Charles River Laboratories (Wilmington, MA). The animals were housed in the Animal Care Facilities of the University of Miami School of Medicine under veterinary supervision, and maintained on regular laboratory food and water ad libitum, and kept on a 12-hr light/dark cycle. 
Neonatal rat pups aged 4-5 days were used for these experiments. Pups from several litters were first mixed and then randomly redistributed to the parent dams (10-12 per dam). Pups were injected intraperitoneally just prior to $\mathrm{O}_{2}$ exposure with either endotoxin (Salmonella typhimurium lipopolysaccharide, Westphal extracted, Difco, $20 \mu \mathrm{g} / \mathrm{kg}$ in $0.3 \%$ saline) or $0.3 \%$ saline using a 30-gauge needle and an injection volume of $50 \mu \mathrm{l} /$ $10 \mathrm{~g}$ body weight. A repeat injection of endotoxin $(40 \mu \mathrm{g} / \mathrm{kg})$ or diluent was given at $24 \mathrm{~h}$ exposure time. Litters were kept with a nursing dam at all times. The dams were rotated between air and $\mathrm{O}_{2}$-exposed litters every $24 \mathrm{~h}$ to prevent $\mathrm{O}_{2}$ toxicity in the nursing dams. Each litter contained both saline- and endotoxintreated pups.

Oxygen exposures were conducted as previously described (5, $10,11)$ in $3.5 \mathrm{ft}^{3}$ plastic isolettes with regular monitoring of $\mathrm{O}_{2}$ $\left(>95 \% \mathrm{O}_{2}\right)$ and $\mathrm{CO}_{2}$ concentrations $(<0.40 \%)$, temperature $(23-$ $\left.25^{\circ} \mathrm{C}\right)$ and humidity $(40-60 \%)$. Exposures were continuous except for a daily 10 - to 15 -min interval to allow for cage changing, dam switching, and pup weighing. After 14 days in $>95 \% \mathrm{O}_{2}$, monitored gas mixtures of $\mathrm{O}_{2}$ and $\mathrm{N}_{2}$ were used to gradually lower the chamber $\mathrm{O}_{2}$ concentration to $21 \% \mathrm{O}_{2}$ over a 24-h "weaning period" $>95 \% \mathrm{O}_{2} \rightarrow 85 \% \mathrm{O}_{2} \rightarrow 70 \% \mathrm{O}_{2} \rightarrow 55 \% \mathrm{O}_{2}$ $\rightarrow 40 \% \mathrm{O}_{2} \rightarrow 30 \% \mathrm{O}_{2} \rightarrow 21 \% \mathrm{O}_{2}$; approximate 4 - to 5 -h period at each intermediary $\mathrm{O}_{2}$ level). Survival was monitored frequently during the weaning period.

Lung analysis/morphometry. In two experiments we removed random pups from each litter after 7 days in $\mathrm{O}_{2}$ (prior to any deaths in $\mathrm{O}_{2}$ ) and sacrificed them and their age-matched room air controls with an overdose of pentobarbital. Following rapid perfusion of the lungs with cold isotonic phosphate buffer $(0.1$ $\mathrm{M}$ potassium phosphate, $0.15 \mathrm{M} \mathrm{KCl}, \mathrm{pH} 7.4$ ), the lungs were weighed, homogenized, and aliquoted as previously described (5, $10,11)$ for spectrophotometric assay of antioxidant enzymes SOD (17), CAT (18), GP (19), G-6-PD (20), protein (21), DNA (22), and RNA (23) content. Purified standards for all these biochemical assays were obtained from Sigma Chemical Co. (St. Louis, MO).

Lung wet weight/dry weight measurements were done on nonperfused pup lungs, weighed in preweighed tins before and after oven $\left(80^{\circ} \mathrm{C}\right)$ drying to constant weight.

For the morphological studies, rat pups were sacrificed at the end of the 14-day period in $>95 \% \mathrm{O}_{2}$ or room air. Lungs were fixed with $10 \%$ buffered formalin via a tracheal cannula, using a constant inflation pressure of $20 \mathrm{~cm} \mathrm{H}_{2} \mathrm{O}$ (fixative), maintained for $48 \mathrm{~h}$ prior to sectioning. No correction was made for tissue shrinkage. Lung volumes were measured by water displacement and specific lung volumes ( $\mathrm{ml} / 100 \mathrm{~g}$ body weight) were calculated. From all lungs, similarly oriented sections from similar portions of the left lung and the right middle and lower lobes were stained with hematoxylin and eosin and initially examined to eliminate any sections with evidence of inadequate preparation (atelectasis). Morphometry was performed utilizing a standard integrating eyepiece with 5 equal lines and 25 intercept bars (Zeiss). The coded slides were examined at $\times 400$ magnification, with 30 random fields counted per slide. We counted the number of times the intercept bars fell on lung tissue per field and the number of times the lines were crossed by tissue septa per field. $\mathrm{L}_{\mathrm{m}}$ was calculated using the formula (24)

$$
\mathrm{L}_{\mathrm{m}}=\frac{\text { length of line } \times \text { no. of lines } \times \text { no. of fields }}{\text { no. of tissue intercepts }}
$$

where length of line is $0.21 \mu \mathrm{m}$, number of lines is 5 , and number of fields is 30 . ISA was calculated using the formula (25)

$$
\text { ISA }=\frac{4 \times \text { lung vol }}{\mathrm{L}_{\mathrm{m}}}
$$

and percent air space by

$$
\% \text { air space }=\mathrm{P}_{\mathrm{A}} /\left(\mathrm{P}_{\mathrm{A}}+\mathrm{P}_{\mathrm{T}}\right)
$$

where $\mathrm{P}_{\mathrm{A}}$ is the number of intercept bars hitting air and $\mathrm{P}_{\mathrm{T}}$ is the number of intercept bars hitting tissue.

After these planned morphometric studies were completed, we unexpectedly had the opportunity to examine toluidine bluestained, epon-embedded, thin sections of lung $(1 \mu \mathrm{m})$ from neonatal rats treated in the same manner as described above with saline or endotoxin ( $n=$ three animals each) and exposed to hyperoxia for 7 days. These thin sections allowed sufficient resolution of the lung parenchyma for morphometric assessment of capillary patency in the lung acini. (These sections were made during an unrelated electron microscope study on airway development by another investigator, Dr. Gloria D. Massaro, Pulmonary Research Division, University of Miami.) The preparation of these sections involved fixation of lungs in situ in anesthetized rats using cold $2.5 \%$ glutaraldehyde in $0.1 \mathrm{M}$ sodium

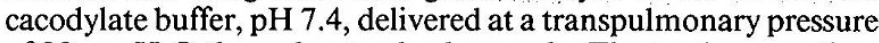
of $20 \mathrm{~cm} \mathrm{H} \mathrm{H}_{2} \mathrm{O}$ through a tracheal cannula. The trachea was then ligated, the lungs removed, and fixation continued for $2 \mathrm{~h}$ at 0 $4^{\circ} \mathrm{C}$. A stratified sample of tissue was obtained by removing one piece from five different areas of the lung: left upper, middle, and lower lung, and right upper and lower lung. These were placed in fresh cacodylate buffer. Blocks were cut from these areas, washed three times in cacodylate buffer, kept at $4^{\circ} \mathrm{C}$ overnight, and then postfixed for $1 \mathrm{~h}$ in $2 \%$ osmium tetroxide in $0.1 \mathrm{M}$ sodium cacodylate buffer, $\mathrm{pH} 7.4$. The tissue was then dehydrated and embedded in Epon. One- $\mu \mathrm{m}$ thick sections were cut and stained with toluidine blue. Using a different lattice grid $(6 \times 7=42$ intercept lines with 84 intercept bars; Zeiss), we counted on coded slides under oil immersion the number of intercept bars falling on alveolar wall capillaries, lung parenchyma, and air spaces. From these values we calculated the "capillary density" in the alveolar walls using the formula: (number of capillary "hits" $\div$ number of capillary "hits" + number of parenchyma "hits"). Sixty to 75 random fields per treatment group were assessed in this manner.

Statistical analysis. Survival rates of the treated versus untreated rat pups were compared by $\chi^{2}$ testing. Analysis of variance testing was used for comparison of lung biochemistry values, morphometric values, and gravimetric values (26), using $p<$ 0.05 as the level of significant differences between treatment groups.

\section{RESULTS}

As indicated before, whereas adult rats tolerate prolonged hyperoxia poorly, with most animals dying by 3 days of exposure to $>95 \% \mathrm{O}_{2}$, neonatal rats tolerate this toxic challenge much better. As seen in Figure 1, nearly $100 \%$ of the two pup groups were alive after 7 days of $\mathrm{O}_{2}$ exposure. Endotoxin treatment had little effect on the survival rate at the end of the 14-day period in high $\mathrm{O}_{2}$ [saline group $=39 / 51(76 \%)$ versus endotoxin group $=41 / 51(80 \%) ; p>>0.05]$. However, a large difference in the comparative survival rates occurred during the weaning period from $>95 \% \mathrm{O}_{2}$ to room air [saline group $=14 / 51(27 \%)$ versus endotoxin $=32 / 51(63 \%) ; p<0.001]$. Of the 39 saline pup survivors after 2 wk in high $\mathrm{O}_{2}, 25(64 \%)$ died when challenged with gradually reduced levels of $\mathrm{O}_{2}$ to breath, while of the 41 endotoxin-treated survivors, only nine $(22 \%)$ succumbed during the transition to room air breathing.

There were no marked differences detectable between the two groups of $\mathrm{O}_{2}$-exposed pups in the degree of lung edema seen microscopically (primarily perivascular) or by gravimetric assessment. For the saline versus endotoxin groups the respective mean lung weight/body weight values were 1.554 versus $1.543(n=9)$ (air control $=1.708$ ); and the lung wet weight/dry weight values were, respectively, 5.973 versus 5.688 (air control $=4.806$ ) (both $p<0.05$ versus air control, but not significantly different compared to one another).

Figure 2 shows the antioxidant enzyme response to hyperoxia in the two groups. Both groups of pups demonstrated the char- 
acteristic neonatal animal rise in all four lung enzymes (8). For SOD, CAT, and GP activities the percent increases in response to $\mathrm{O}_{2}$ exposure were very similar in the two pup groups. The G6-PD activity change was higher in the $\mathrm{O}_{2}$-endotoxin group $(+141 \%)$ versus the saline group $(+98 \%)(p<0.07)$. There were no differences between the $\mathrm{O}_{2}$-exposed groups in the other biochemical parameters examined-lung protein and DNA and RNA content (Table 1).

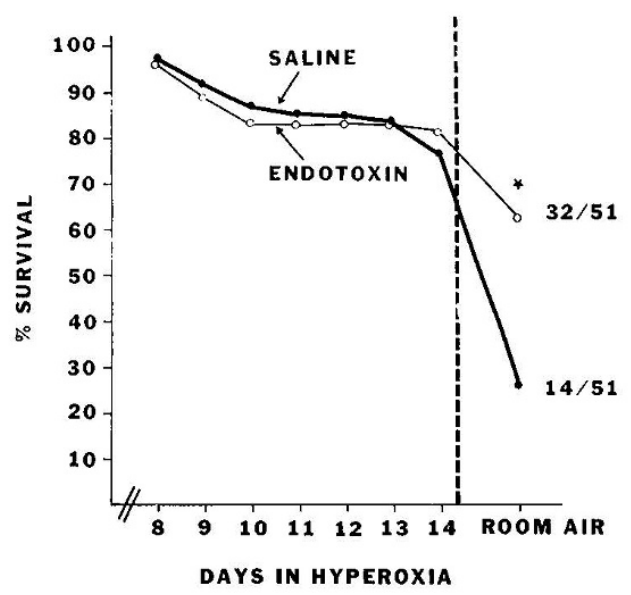

Fig. 1. Survival of neonatal rat pups during and postexposure to $>95 \% \mathrm{O}_{2}$. The $\mathrm{O}_{2}$ concentration was gradually reduced from $>95 \% \mathrm{O}_{2}$ $\rightarrow 85 \% \mathrm{O}_{2} \rightarrow 70 \% \mathrm{O}_{2} \rightarrow 55 \% \quad \mathrm{O}_{2} \rightarrow 40 \% \mathrm{O}_{2} \rightarrow 30 \% \mathrm{O}_{2} \rightarrow 21 \% \mathrm{O}_{2}$ over the 24-h period after 14 days in $>95 \% \mathrm{O}_{2}$. Numbers $=$ number of rats surviving/number at start of exposure. ${ }^{*} p<0.001$ for comparison of $\mathrm{O}_{2}$-saline and $\mathrm{O}_{2}$-endotoxin $\left(\chi^{2}\right.$ test).

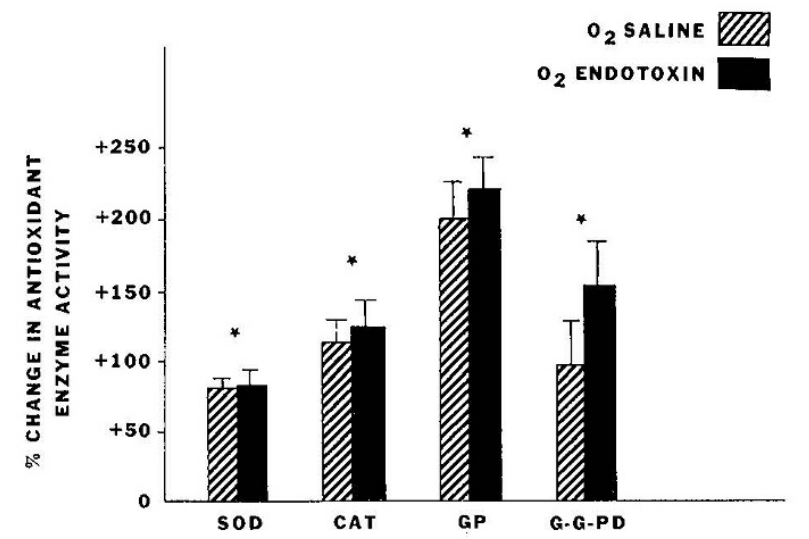

Fig. 2. Lung antioxidant enzyme response of neonatal rats to exposure to $>95 \% \mathrm{O}_{2}$ for 7 days. Values are $\%$ increase in activity compared to air control lung enzyme levels which were, per mg DNA-SOD $=15.4$ $\mathrm{U}: \mathrm{CAT}=811 \mathrm{IU} ; \mathrm{GP}=0.834 \mu \mathrm{Mol}$ NADPH oxid $/ \mathrm{min} ; \mathrm{G}-6-\mathrm{PD}=$ $0.307 \mu \mathrm{Mol}$ NADP red/min. Values are means \pm SE bar, $n=$ six per group. ${ }^{*} p<0.05$ versus air control values.
The typical microscopic appearance of the lungs from the experimental rat pups (age $\sim 19$ days) are shown in Figure 3. The coded slides could easily be separated into air-control and $\mathrm{O}_{2}$-exposed groups by low-power inspection of the general size of the air spaces; the appearance of many smaller diameter alveoli in the unexposed animal lungs was in distinct contrast to the larger diameter air saccules in the $\mathrm{O}_{2}$-exposed pup lungs. Qualitatively, lung sections from all the $\mathrm{O}_{2}$-exposed pups examined, endotoxin-treated and saline-treated, demonstrated marked inhibition of normal alveolarization. By morphometric analysis, however, as summarized in Table 2, significant quantitative differences between the two $\mathrm{O}_{2}$-exposed groups became apparent. The difference involved 1) the mean airspace size, with less elevated $\mathrm{L}_{\mathrm{m}}$ values after $\mathrm{O}_{2}$ exposure in the endotoxin-treated pup lungs; 2) a greater preservation of ISA for respiratory exchange in these endotoxin-treated pup lungs; and 3) increases in specific ISA in these lungs, indicating a greater potential area for oxygenating the blood per unit of body mass requiring oxygenation. The endotoxin-treated $\mathrm{O}_{2}$-exposed pups' lungs also showed significantly increased absolute and specific lung volumes (Table 2) which contributed to the calculated change in ISA (ISA $=4$ $\times$ lung volume $\div \mathrm{L}_{\mathrm{m}}$ )

For the morphometric assessment of capillary patency after 7 days in hyperoxia (slides prepared and provided by Dr. Gloria D. Massaro), the results indicate that the calculated mean capillary densities after $\mathrm{O}_{2}$ exposure were consistently depressed in the (3) $\mathrm{O}_{2}$-saline animals with values of $16.37,20.39$, and $18.80 \%$ (total lung fields examined $=67$ ) compared to the values of $27.09,22.65$, and $24.75 \%$ (76 fields) for the $\mathrm{O}_{2}$-endotoxin animal lungs and to the air controls $(29.06,26.76$, and $27.27 \%)-$ evidence of significantly greater preservation of pulmonary microvascular patency in the endotoxin-treated neonatal rat lungs after high $\mathrm{O}_{2}$ exposure. The overall mean $( \pm 1 \mathrm{SD})$ values for alveolar capillary density were $\mathrm{O}_{2}$-saline $=18.52 \pm 1.65 \% *, \mathrm{O}_{2-}$ endotoxin $=24.83 \pm 2.10 \%$, and air control $=27.70 \pm 1.21 \%$ ( ${ }^{*} p<0.05$ compared to air control or $\mathrm{O}_{2}$-endotoxin). These findings are illustrated by the representative photomicrographs of Figure 4.

\section{DISCUSSION}

The concept that immature or neonatal animals have superior tolerance and survival rates in hyperoxia compared to mature animals is supported by multiple experimental studies (dating back for $\sim 50 \mathrm{yr})(1,2,8,27-29)$. Several recent studies, however, have emphasized that specific forms of lung injury may be occurring during prolonged high $\mathrm{O}_{2}$ exposure of neonatal animals that standard survival studies and standard pathological assessments for evidence of acute pulmonary injury (interstitial, perivascular, and intraalveolar edema, lung hemorrhage, lung inflammatory cell influx) may have overlooked previously (5-8, 30 ). These other deleterious effects of hyperoxia are age specific, in that they occur in the setting of high $\mathrm{O}_{2}$ exposure during a period of normally rapid growth and differentiation of the lung. In the rat (as well as other common small laboratory animals, with the exception of the guinea pig) $(8,31-34)$, the early postnatal period is when most of the developmental process of

Table 1. Lung biochemical parameters in $\mathrm{O}_{2}$-exposed rat pups*

\begin{tabular}{lllcc}
\hline & $\begin{array}{c}\text { Protein } \\
(\mathrm{mg} / \mathrm{lung})\end{array}$ & $\begin{array}{c}\text { DNA (mg/ } \\
\text { lung) }\end{array}$ & $\begin{array}{c}\text { RNA (mg/ } \\
\text { lung) }\end{array}$ & RNA/DNA \\
\hline Air controls $(n=12)$ & $27.2 \pm 2.8$ & $4.38 \pm 0.35$ & $1.61 \pm 0.21$ & $0.372 \pm 0.025$ \\
$\mathrm{O}_{2}$-saline $(n=9)$ & $29.8 \pm 3.3$ & $3.05 \pm 0.31 \dagger$ & $1.65 \pm 0.16$ & $0.544 \pm 0.049 \dagger$ \\
$\mathrm{O}_{2}$-endotoxin $(n=9)$ & $30.5 \pm 3.7$ & $3.12 \pm 0.29 \dagger$ & $1.62 \pm 0.20$ & $0.523 \pm 0.033 \dagger$ \\
\hline
\end{tabular}

* Neonatal rats exposed to $>95 \% \mathrm{O}_{2}$ for 7 days (or room air). Pups were injected either with endotoxin just prior to start of $\mathrm{O}_{2}$ exposure (20 $\mu \mathrm{g} /$ $\mathrm{kg}$ ) and at $24 \mathrm{~h}$ of exposure time $(40 \mu \mathrm{g} / \mathrm{kg})$ or with equivolume $0.3 \%$ saline. Air controls also received endotoxin or saline and due to similar biochemical parameters, results pooled as single air control group.

$\dagger p<0.05$ compared to air control values (results $=$ mean $\pm 1 \mathrm{SD}$ ). 

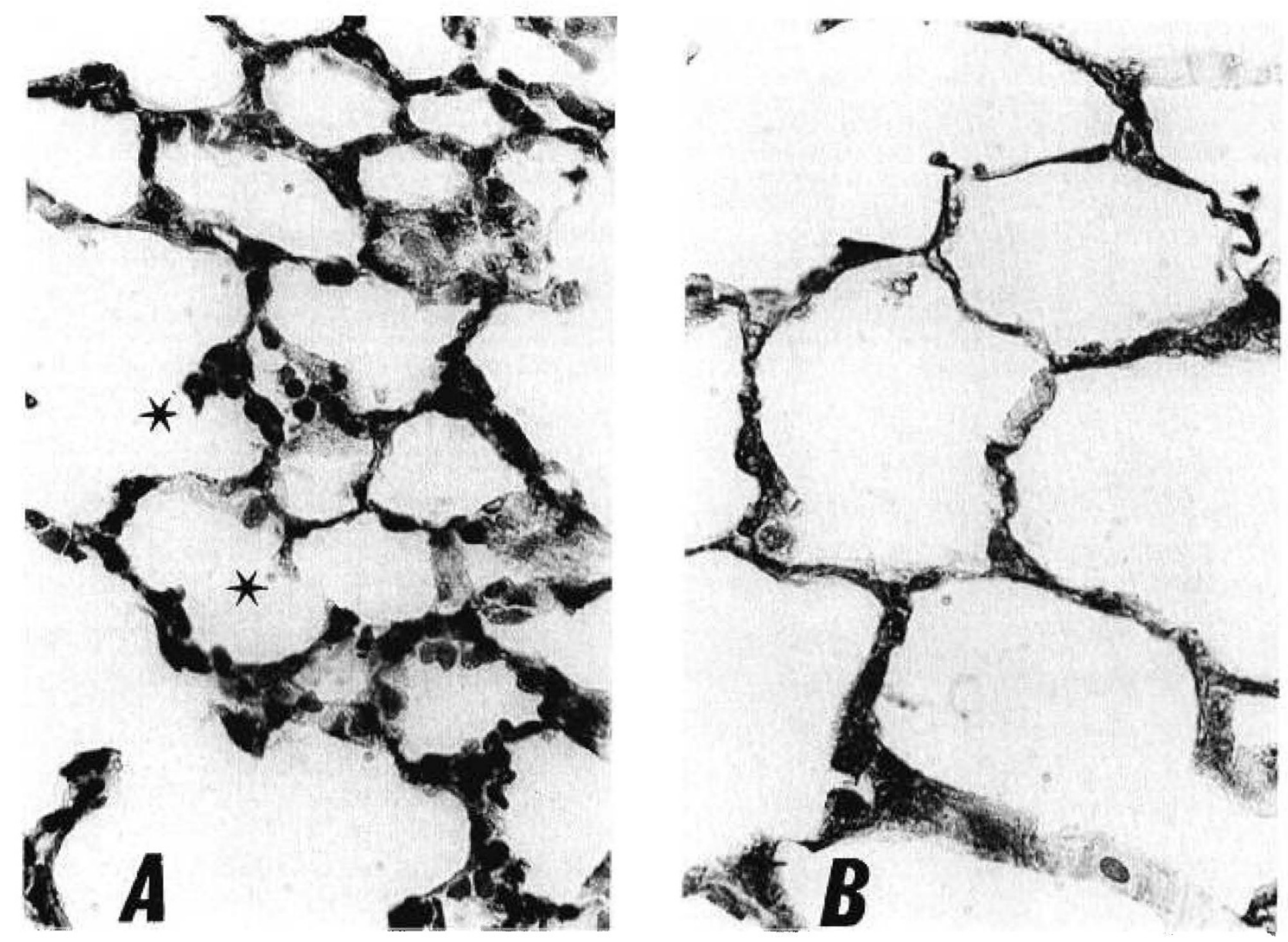

Fig. 3. Lungs from neonatal rat pups exposed to $>95 \% \mathrm{O}_{2}$ or room air for 14 days. $A$, air control lung shows many small alveoli formed and active septal bud formation (*). $B, \mathrm{O}_{2}$-exposed lung shows retarded alveoli formation with larger lung saccules and stunted septal buds. Hematoxylin and eosin stain, $\times 250$.

Table 2. Morphometric analysis of $\mathrm{O}_{2}$-exposed neonatal rat

\begin{tabular}{lccc}
\multicolumn{4}{c}{ pups $^{*}$} \\
\hline & $\begin{array}{c}\text { Air controls } \\
(n=5)\end{array}$ & $\begin{array}{c}\mathrm{O}_{2} \text {-saline } \\
(n=5)\end{array}$ & $\begin{array}{c}\mathrm{O}_{2} \text {-endotoxin } \\
(n=6)\end{array}$ \\
\hline Body wt $(\mathrm{g})$ & $31.2 \pm 1.2$ & $29.5 \pm 2.0$ & $27.3 \pm 2.1$ \\
Lung volume $(\mathrm{ml})$ & $1.27 \pm 0.03$ & $1.33 \pm 0.19$ & $1.45 \pm 0.09 \dagger$ \\
Specific lung volume & $4.08 \pm 0.13$ & $4.50 \pm 0.47$ & $5.33 \pm 0.65 \dagger, \S$ \\
$\quad(\mathrm{ml} / \mathrm{l} 00 \mathrm{~g}$ body wt) & & & \\
$\%$ air space & $73.0 \pm 0.7$ & $78.0 \pm 1.7 \dagger$ & $76.1 \pm 2.3$ \\
$\left(\mathrm{~L}_{\mathrm{m}}=\mu \mathrm{m}\right)$ & $43.3 \pm 1.6$ & $55.8 \pm 4.3 \dagger$ & $49.0 \pm 5.1 \dagger$ \\
$\left(\mathrm{ISA}=\mathrm{cm}^{2}\right)$ & $1167 \pm 27$ & $954 \pm 68 \dagger$ & $1058 \pm 91$ \\
Specific ISA $\left(\mathrm{cm}^{2} /\right.$ & $3753 \pm 185$ & $3232 \pm 143 \dagger$ & $4393 \pm 289 \S$ \\
$\quad 100$ g body wt) & & &
\end{tabular}

* Neonatal rats exposed to $>95 \% \mathrm{O}_{2}$ (or room air) for 14 days and treated with endotoxin or saline as detailed in Table 1 .

$\dagger p<0.05$ for comparison of $\mathrm{O}_{2}$-exposed to air controls.

$\S p<0.05$ for comparison of $\mathrm{O}_{2}$-endotoxin verstis $\mathrm{O}_{2}$-saline (values $=$ mean $\pm 1 \mathrm{SD})$.

lung alveolarization will occur, and when rapid lung cell biosynthesis and replication is normally taking place.

This is understandably therefore a period when the known inhibiting effects of high $\mathrm{O}_{2}$ on cellular nucleotide and protein synthesis $(1,3,4,28,29)$ could produce serious interference with normal lung morphological and functional development. Roberts et al. and others (5-8) have demonstrated this high $\mathrm{O}_{2-}$ induced inhibition of normal alveolarization -with stunting of the septal buds that normally grow out to divide the larger air saccules of the newborn lung into smaller adult-like alveolar air sacs. Lung microvascular development, which normally parallels the alveolarization process, is concurrently suppressed by hyperoxic exposure during the early postnatal period $(5,8,35)$. It is important to mention that the evidence available to date suggests that when inhibition of normal organ (lung) development is inhibited by $\mathrm{O}_{2}$ or other toxic influences during the "critical period" when the normal maturation changes should occur, permanent alterations of organ (lung) structure (and function) result $(5,6,35-37)$. Thus, while neonatal animals may demonstrate prolonged "tolerance" to pulmonary $\mathrm{O}_{2}$ toxicity and longterm survival during the period of exposure to high levels of $\mathrm{O}_{2}$, chronic sequelae are likely to be evolving which may only become evident postexposure, when underdevelopment of the lungs and compromised respiratory reserve function become manifest when the animals are returned to room air breathing.

This tableau is what we believe we witnessed in the neonatal rat pups we exposed for 14 days to $>95 \% \mathrm{O}_{2}$, an exposure period which was designed to span chronologically the normal period of maximal alveolarization in this species $(32,33)$. The striking inhibition of normal small alveoli formation-a morphological process which greatly enhances the surface area of the lung for physiological respiratory exchange-is evident in Figure 3 . The poor ability of the control (saline treated) rat pups to survive the transition from $>95 \% \mathrm{O}_{2}$ to room air can be interpreted to reflect the poor respiratory reserve capacity in these pups due to their severely inhibited lung development. The much improved ability of the endotoxin-treated pups to weather this same transition to ambient $\mathrm{O}_{2}$ levels could reflect a lesser degree of interference with lung development in these pups or/and a substantial reduc- 

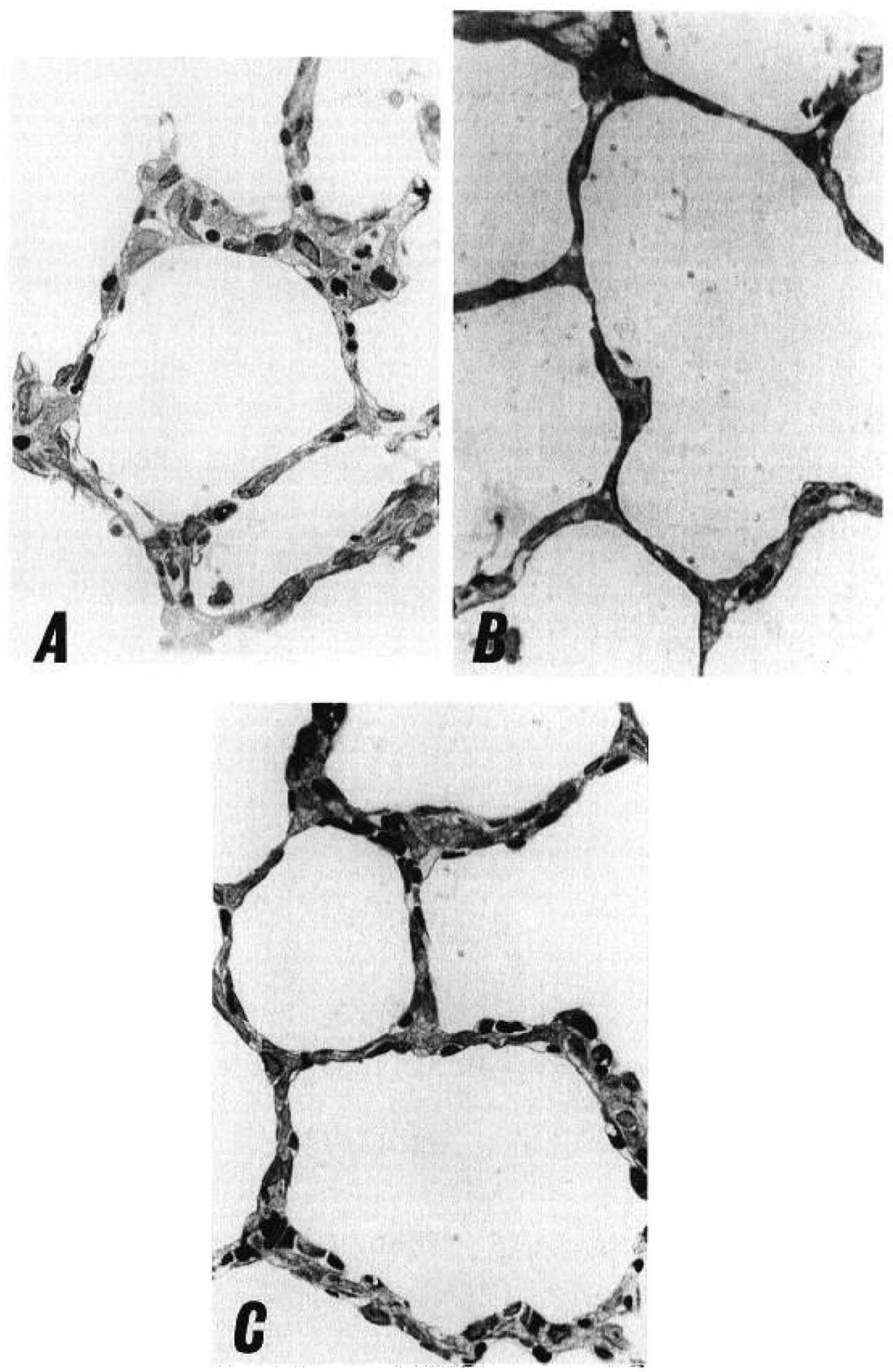

Fig. 4. Lungs from neonatal rat pups exposed to $>95 \% \mathrm{O}_{2}$ or room air for 7 days. $A$, air control lung shows normal prominent capillarity in alveolar septa. $B$, lung from saline-treated pup has reduced capillary density after $\mathrm{O}_{2}$ exposure. $C$, lung from $\mathrm{O}_{2}$-exposed endotoxin-treated pup shows preservation of alveolar wall capillary patency. Toluidine-blue stain, $\times 450$. 
tion of $\mathrm{O}_{2}$-induced damage to the existent alveolar-capillary units of the lung. The morphometric data would suggest both a lesser loss of internal surface area for potential respiratory exchange (Table 2) and a reduced destruction of capillarity in the septal walls of the pups which were treated with endotoxin. The problem of returning animals to room air after prolonged high $\mathrm{O}_{2}$ exposure was addressed in an earlier study on $\mathrm{O}_{2}$ toxicity in monkeys by Kapanci et al. (38). They concluded that due to $\mathrm{O}_{2-}$ induced damage and obliteration of many lung capillaries with subsequent altered local ventilation-perfusion ratios, plus thickened respiratory membranes reducing the ease of gaseous diffusion, their (adult) animals could not maintain a reasonable $\mathrm{pO}_{2}$ level in their arterial blood to allow survival in ambient air.

We chose endotoxin as a prophylactic pharmacological agent in these studies based on previous knowledge of the positive effects of low-dose endotoxin treatment in hyperoxia-stressed (10-15) and pneumonectomized-stressed adult rat lungs (16). In addition to markedly improving survival of adult rats in high $\mathrm{O}_{2}$ (39), endotoxin treatment is associated with preservation of lung capillary integrity $(40)$ and capillary endothelial cell metabolic function (5-hydroxytryptamine uptake) (41), and preservation of lung protein/nucleotide synthetic capability $(14,15)$. Since hyperoxia will impair these processes in untreated young animals also-processes important to both lung growth and lung repair capabilities-we hypothesized that endotoxin treatment would have a beneficial effect in the neonatal animals challenged with prolonged high $\mathrm{O}_{2}$ exposure.

In human infants who develop chronic lung disease (BPD) during treatment for immature lung problems, the major focus has been on the degree of lung damage that has occurred due to the prolonged and usually complicated course of assisted ventilation and high $\mathrm{O}_{2}$ therapy (42). Weaning these infants back to room air breathing may be a drawn out or in some cases impossible task. Again, while lung tissue destruction may be profound in many infants with BPD, the additional factor of inhibition of normal lung growth and alveolarization due to prolonged high $\mathrm{O}_{2}$ exposure is likely to play an important role in determining the outcome and potential for a reasonable degree of recovery in many BPD patients. Several recent reports, including that by Sobonya, et al. (43) would seem to support the contention $(42-45)$ that inhibited alveolarization and reduced surface area for respiratory exchange can be a serious consequence of prolonged respiratory support for BPD.

\section{CONCLUSIONS}

We conclude from our present studies that endotoxin treatment did have a protective effect against the consequences of prolonged high $\mathrm{O}_{2}$ exposure in the neonatal rat. The protective effect was apparent only after the $\mathrm{O}_{2}$ exposure was ended and the surviving animals were tested for their ability to readapt to room air breathing. Our data imply that even though normal sized alveoli were not formed in the endotoxin-protected pups, sufficient increase in functional surface area did develop during the growth period in $\mathrm{O}_{2}$ to prevent serious hypoxemia on return to room air. Also, although it was only assessed after 7 days of $\mathrm{O}_{2}$ exposure, the microvascular component of the respiratory membrane of the lung which is usually very sensitive to hyperoxic-damage and obliteration, was significantly better preserved in the endotoxin-treated pups' lungs compared to the salinetreated neonates. How endotoxin interacts with the developing lung to ameliorate the consequences of prolonged high $\mathrm{O}_{2}$ exposure will require future studies to unravel.

Acknowledgments. The author thanks Mr. Miguel Martinez and $\mathrm{Mr}$. Rey Sio for expert technical assistance and Mrs. Ondina Garcia-Pons for assistance with the manuscript preparation.

\section{REFERENCES}

1. Clark JM, Lambertson CJ 1971 Pulmonary oxygen toxicity: a review. Pharmacol Rev 23:37-133

2. Frank L, Bucher JR, Roberts RJ 1978 Oxygen toxicity in neonatal and adult animals of various species. J Appl Physiol 45:699-704

3. Northway WH Jr, Rezcan L, Petriceks R. Bensch KG 1967 Oxygen toxicity in the newborn lung: reversal of inhibition of DNA synthesis in the mouse. Pediatrics 57:41-46

4. Massaro D 1985 Protein turnover in the lungs. In: Fishman AP. Fisher A (eds) Handbook of Physiology-The Respiratory System. I. Circulation and Nonrespiratory Functions. Williams \& Wilkins Co, Baltimore, pp 277-308

5. Frank L. Groseclose EE 1982 Oxygen toxicity in newborns: the adverse effects of undernutrition. J Appl Physiol 53:1248-1255

6. Roberts RJ, Weesner KM, Bucher JR 1983 Oxygen-induced alterations in lung vascular development in the newborn rat. Pediatr Res 17:368-375

7. Bucher JR, Roberts RJ 1981 The development of the newborn rat lung in hyperoxia: a dose-response study of lung growth, maturation, and changes in antioxidant enzyme activities. Pediatr Res 15:999-1008

8. Frank L 1985 Effects of oxygen on the newborn. Fed Proc 44:2328-2334

9. Massaro D, Teich N, Massaro GD 1986 Postnatal development of pulmonary alveoli: modulation in rats by thyroid hormones. Am J Physiol 250:R51R55

10. Frank L, Summerville J, Massaro D 1980 Protection from oxygen toxicity with endotoxin: role of the endogenous antioxidant enzymes of the lung. $J$ Clin Invet 65:1104-1110

11. Frank L, Neriishi K 1984 Endotoxin treatment is able to protect vitamin E deficient rats from pulmonary $\mathrm{O}_{2}$ toxicity. Am J Physiol 247:R520-R526

12. Block ER 1983 Endotoxin protects against hyperoxic alterations in lung endothelial cell metabolism. J Appl Physiol 54:24-30

13. Jenkinson SG, Long RJ, Lawrence RA. Endotoxin protects selenium-deficient rats from hyperoxia. J Lab Clin Med 103:143-15I

14. Koizumi M, Frank L. Massaro D 1985 Mitogenic effect of endotoxin on lung and tolerance of rats to hyperoxia. J Appl Physiol 59:315-319

15. Hass M, Frank L. Massaro D 1982 The effect of bacterial endotoxin on synthesis of (Cu. $\mathrm{Zn}$ )superoxide dismutase in lung of oxygen-exposed rats. $J$ Biol Chem 257:9379-9383

16. Sosenko IRS, Frank L 1985 Endotoxin alters biochemical and morphometric responses to pneumonectomy in adult rats. Am J Physiol 249:R125-R132

17. McCord JM. Fridovich I 1969 Superoxide dismutase: an enzymic function for erythocuprein (hemocuprein). J Biol Chem 244:6049-6055

18. Holmes RS, Masters CJ 1970 Epigenetic interconversion of the multiple forms of mouse liver catalase. FEBS Lett 11:45-48

19. Paglia DE, Valentine WN 1967 Studies on the quantitative and qualitative characteristics of erythrocyte glutathione peroxidase. J Lab Clin Med 70:158169

20. Langdon RG 1966 Glucose-6-phosphate dehydrogenase from erythrocytes. In: Colowick SP, Kaplan NO (eds) Methods in Enzymology. Academic Press, New York, pp 126-131

21. Schacterle RE. Pollack RL 1973 A simplified method for the quantitative assay of small amounts of protein in biological material. Anal Biochem 51:654655

22. Richards GM 1974 Modifications of the diphenylamine reaction giving increased sensitivity and simplicity in the estimation of DNA. Anal Biochem 57:369-376

23. Schneider WC 1956 Determination of nucleic acids in tissue by pentose analysis. In: Colowick SP, Kaplan NO (eds) Methods in Enzymology, Vol 3. Academic Press. New York, pp 680-684

24. Thurlbeck WM. Galaugher W. Mathers J 1981 Adaptive response to pneumonectomy in puppies. Thorax 36:414-427

25. Weibel ER 1963 Morphometry of the Human Lung. Academic Press, New York, pp 51-73

26. Steel RG. Torric JH 1966 Principles and Procedures of Statistics. McGrawHill, New York, pp 99-131

27. Smith FJC, Bennett GA, Heim JW, Thomson RM, Drinker CK 1932 Morphological changes in the lungs of rats living under compressed air conditions. J Exp Med 56:79-93

28. Shanklin DR 1969 On the pulmonary toxicity of oxygen. I. Relationship of oxygen content to the effect of oxygen on the lung. Lab Invest 21:439-448

29. Huber GL, Drath DB 1981 Pulmonary oxygen toxicity. In: Gilbert DL (ed) Oxygen and Living Processes. An Interdisciplinary Approach. SpringerVerlag, New York, pp 273-342

30. Bartlett D 1970 Postnatal growth of the mammalian lung: influence of low and high oxygen tensions. Respir Physiol 9:58-64

31. Lechner AJ, Banchero N 1982 Advanced pulmonary development in newborn guinea pigs (Cavia porcellus). Am J Anat 163:235-246

32. Burri PH. Dbaly J. Weibel ER 1974 The postnatal growth of the rat lung. I. Morphometry. Anat Rec 178:711-730

33. Burri PH 1974 The postnatal growth of the rat lung. III. Morphology. Anat Rec 180:77-98

34. Crocker TT. Teeter A, Nielsen B 1970 Postnatal cellular proliferation in mouse and hamster lung. Cancer Res 30:357-361

35. Shaffer SG. O'Neill DH. Thibeault DW 1986 High plasma concentration of superoxide dismutase (SOD) in hyperoxic neonatal rats fails to prevent chronic vascular pulmonary dysplasia (VPD). Pediatr Res 20:440A

36. Massaro D. Teich N, Maxwell S, Massaro GD, Whitney P 1985 Postnatal 
development of alveoli: regulation and evidence for a critical period in rats. J Clin Invesi 76:1297-1305

37. Todd L. Mullen M, Olley PM, Rabinovitch M 1985 Pulmonary toxicity of monocrotaline differs at critical periods of lung development. Pediatr Res 19:731-7.37

38. Kapanci Y. Weibel ER. Kaplan HP. Robinson FR 1969 Pathogenesis and reversibility of the pulmonary lesions of oxygen toxicity in monkeys. II. Ultrastructural and morphometric studies. Lab Invest 20:101-118

39. Frank L. Roberts RJ 1979 Endotoxin protection against oxygen-induced acute and chronic lung injury. J Appl Physiol 47:577-581
40. Frank L. Roberts RJ 1979 Oxygen toxicity: protection of the lung by bacterial lipopolysaccharide (endotoxin). Toxicol Appl Pharmacol 50:371-380

41. Block ER. Patel JM. Sheridan NP 1986 Endotoxin protects against hypcroxic decrease in membrane fluidity in endothelial cells but not in fibroblasts. Lab Invest 54:146-153

42. O’Brodovich HM. Mellins RB 1985 Bronchopulmonary dysplasia: Unresolved neonatal acute lung injury. Am Rev Respir Dis 132:694-709

43. Sobonya RE, Logvinoff MM, Taussig L, Theriault A 1983 Morphometric analysis of the lung in prolonged bronchopulmonary dysplasia. Pediatr Res $16: 969-972$ 